4 Monsanto Technical Bulletin/PL-306A, Monsanto Company, St Louis (undated)

5 Hutzinger, O., Safe, S., and Zitko, V., Bull. Env. Contam. Toxicol., 6, 209 (1971).

${ }^{6}$ Chlorinated Hydrocarbons in the Marine Environment (US

National Academy of Sciences, Washington DC, 1972).

7 Holden, A. V., and Marsden, K., Nature, 216, 1274 (1967).

8 Jensen, S., Johnels, A. G., Olsoon, M., and Otterlind, G., Nature, 224, 247 (1969)

${ }^{9}$ Risebrough, R. W., Chemical Fallout, First Rochester Conference on Toxicity (1969).

10 Duke, T. W., Lowe, J. J., and Wilson, A. J., Bull. Env. Contam. Toxicol., 5, 171 (1970).

${ }^{11}$ Schmidt, T. T., Risebrough, R. W., and Gress, F., Bull. Env. Contam. Toxicol., 6, 235 (1971).

12 Curl, jun., H. C., dissertation, Florida State Univ. (1956).

13 Zitko, V., Bull. Env. Contam. Toxicol., 5, 279 (1970).

14 Mosser, J. L., Fisher, N. S., Teng, T.-C., and Wurster, C. F., Science, 175, 191 (1972).

15 Keil, J. E., Priester, L. E., and Sandifer, S. H., Bull. Env. Contam. Toxicol., 6, 156 (1971).

16 Wurster, jun., C. F., Science, 159, 1474 (1968).

17 Menzel, E. W., Anderson, J., and Randtke, A., Science, 167, $1724(1970)$.

18 Mosser, J. L., Fisher, N. W., and Wurster, C. F., Science, 176, 533 (1972).

\section{Organochlorine Levels in Atlantic Seabirds}

SYNTHETIC organochlorine derivatives have been found in a variety of seabirds from the eastern North Pacific ${ }^{1}$ and even the Antarctic ${ }^{2}$, and considerable amounts of polychlorinated biphenyls (PCBs) in particular have been found in birds from the Baltic ${ }^{3}$, Dutch waters ${ }^{4}$ and the livers of starving common guillemots, Uria aalge, washed ashore around the Irish Sea in the autumn of $1969^{5}$. But comparatively few estimates of the amounts present in normal seabirds from the open North Atlantic have yet been published. We are reporting elsewhere ${ }^{6}$ the results of the investigation of over 100 birds from a representative range of species occurring between Scotland and the Arctic. In general they were all found to contain mainly PCBs and $p p^{\prime}$-DDE, the former in greater concentration in every bird examined, in marked contrast to the North Pacific, where DDE levels are normally higher ${ }^{1}$. The ratio of PCB to DDE was usually between two and ten in all species with the exception of the kittiwake, Rissa tridactyla, where the ratio was always higher. It is difficult to measure DDE in the presence of relatively high amounts of PCBs but in some of the kittiwakes this ratio was at least 60 . This suggests that kittiwakes have a food source relatively high in PCBs compared with the other species or, less likely, that they metabolize or excrete DDE more rapidly than the other species.

The total organochlorine content in muscle and liver was generally low in the auks and the few shearwaters examined, between $0.1-1.0$ parts per million. The levels were higher in more pelagic species, in the kittiwake, fulmar, Fulmarus glacialis, and British storm-petrel, Hydrobates pelagicus, generally $1-10$ p.p.m, and the highest levels rising above 10 p.p.m were found in large gulls and skuas feeding largely around trawlers in the winter and seabird breeding stations in the summer. In all the birds caught or shot the liver levels were normally of the same order as those in muscle, whilst in the birds found dead on beaches the liver levels were normally markedly raised compared to those in muscle. A common guillemot chick only contained a tenth the amount found in the adult accompanying it, so that it would appear that the organochlorine content is not inherited. The stomach oil of a fulmar which it feeds to its chick contained only 1.3 p.p.m. PCBs compared to 1.5 p.p.m. in the liver, 2.3 p.p.m. in the muscle and 42 p.p.m. in the fat, so that it appears that the parent does not pass on the levels found in the fat.

There was no substantial difference in the organochlorine content of birds obtained around the north of Scotland, the Faroes, and in the Barents Sea, and only the puffins Fratercula arctica began to show a diminution in the Davis Strait. Indeed, the highest levels were found in glaucous gulls, Larus hyperboreus, breeding above the seabird colonies on the cliffs of Bear Island. Normal birds, which appeared from regurgitated pellets to have been feeding largely on other seabirds' eggs, had an average content of 24 p.p.m. PCBs and 17 p.p.m. DDE in the liver, and one had 535 p.p.m. PCB and 67 p.p.m. $\mathrm{DDE}$ in the fat. Another bird showed a curious weakness and failure of coordination of the limbs, especially the legs, so that it fell sideways and threw itself about in a convulsion when it was approached so that it was easily caught by hand. On dissection, it was wasted and underweight but otherwise appeared normal. Its liver contained 311 p.p.m. PCBs and 67 p.p.m. DDE. Experimentally poisoned finches showed similar neurological signs and were found to have a mean liver PCB content of 345 p.p.m. at a dose rate sufficient to cause $50 \%$ mortality ${ }^{7}$. Thus this level of 311 p.p.m. PCBs in combination with DDE, which is also known to cause increased retention of PCBs mobilized from fat in starving robins Erithacus rubecula ${ }^{8}$, is a possible cause of the symptoms. Whatever the cause of the bird's decline in condition and convulsions, it seems a matter for concern that such high levels of organochlorine can now be found in the Arctic over 250 miles north of the mainland and in a species which never migrates far south in an area where the surface seawater probably does not even originate in Europe, but in the western North Atlantic.

Specimens used in this study were collected during an investigation of the ecology of birds at sea, financed by the Natural Environment Research Council. We thank Professor E. Brun of Tromsö University who arranged for the second author to visit Bear Island, and Mrs C. Gallacher for technical assistance.

University of Glasgow, Department of Veterinary Pharmacology, Veterinary Hospital, Bearsden, Glasgow G61 $1 Q H$

W. R. P. BOURNE

The Seabird Group, Zoology Department,

Tillydrone Avenue, Aberdeen AB9 $2 T N$

Received May 26; revised August 11, 1972.

${ }^{1}$ Risebrough, R. W., Reicher, P., Peakall, D. B., Herman, S. G., and Kirven, M. N., Nature, 220, 1098 (1968).

2 Tatton, J. O'G., and Ruzicka, J. H. A., Nature, 215, 346 (1967).

3 Jensen, S., Johnels, A. H., Olsson, M., and Otterlind, G., Nature, 224, 247 (1969).

${ }^{4}$ Koeman, J. H., Ten Noever de Braw, M. C., and de Vos, R. H., Nature, 221, 1126 (1969)

s Holdgate, M. W., The Seabird Wreck of 1969 in the Irish Sea (Natural Environment Research Council, 1971).

6 Bogan, J., and Bourne, W., Mar. Pollut. Bull. (in the press).

7 Prestt, I., Jefferies, D., and Moore, N., Environ. Pollut., 1, 3 (1970).

8 Sodergren, A., and Uifstrand, S., Ambio., 1, 36 (1972).

\section{PCB Contamination from Boat Bottom Paint and Levels of PCB in Plankton outside a Polluted Area}

SAMPLES of zoo- and phytoplankton were collected in Stockholm harbour during an investigation into levels of polychlorinated biphenyls (PCBs). The samples were taken in September and October 1971 and in June 1972 at the localities shown in Fig. $2 a$ and $b$. The opportunity was taken to check the possibility that contamination of plankton samples might occur from the anti-fouling paint, containing $\mathrm{PCB}$, used on the boat.

Plankton samples were taken at various locations around the boat in a $0.1 \mathrm{~mm}$ mesh net at a trawling speed of about 1 knot. They were analysed within three days of collection. PCB contents were determined in terms of the extractable fat because of the difficulty in determining the true sample weight.

The plankton was homogenized and extracted as described previously $^{\mathbf{1}}$; extracted fat was weighed and dissolved in 